\title{
THE RIGHT OF AUTHORSHIP ON A WORK
}

\author{
C. R. Romiţan
}

\section{Ciprian Raul Romiţan}

Lawyer - Bucharest Bar

Managing Editor Romanian Intellectual Property Review

*Correspondence: Ciprian Raul Romiţan, S.C. Roş şi Asociaţii, 35 Mircea Vodă St., bl. M27, fl. 6, ap. 16-18, 3 District, Bucharest, Romania

E-mail: ciprian.romitan@asdpi.ro

\begin{abstract}
The moral rights represent the legal expression of the relationship between the work and its creator; they precede, survive and exert a permanent influence on the economic rights. Moral rights are independent of economic rights, the author of a work preserving these rights even after the transfer of its property rights.

The right to claim recognition as the author of the work, called in the doctrine as the "right of paternity of the work" is enshrined in art. 10 lit. b) of the law and it is based on the need to respect the natural connection between the author and his work. The right to authorship is the most important prerogative that constitutes intellectual property rights in general and consists of recognizing the true author of a scientific, literary or artistic work.
\end{abstract}

Key words: author, copyright, moral right, the right of authorship, The Berne Convention from 1886, The Rome Conference from 1928

\section{Introduction}

The Berne Convention for the protection of literary and artistic works of September 9, $1886^{1}$, which is the first and primary mean of international protection of copyright of literary, artistic and scientific works, didn't provide exclusive dispositions on which the moral rights of the author to be recognized as a separate faculty of law operating separately from the economic rights. In 1926, during a course held at the Hague National Law Academy, the Italian jurist Francesco Ruffini, a professor at the University of Turin, prophesied, saying that the moral right of the author "is about to become a dogma of international common law".

Following the research in the field of doctrine and jurisprudence, during the Rome Conference of $1928^{2}$, when there was a second revision of the Berne Convention, it was decided the existence of authors moral rights and also the introduction of article 6 bis under the following form: "Independent of the economic rights, and even after the transfer of those rights, the author retains the right to claim the authorship of the work and the right to object to any distortion, mutilation or other change of that work which would be prejudicial to its honour or reputation (paragraph 1). It is reserved for the national legislation of the Union Countries to establish the conditions for exercising these rights. The means to defend them will be governed by the laws of the country where the protection is required (paragraph 2)".

\footnotetext{
${ }^{1}$ The Berne Convention for the protection of literary and artistic works of September 9, 1886, revised at Berlin on 13 November 1908 at Rome on June 2, 1928, published in the Official Gazette of Romania no. 123 of 31 May 1935. Romania joined the Berne Convention according to Law no. 77/1998, published in the Official Gazette of Romania, Part I, No. 156 of 17 April 1998.

${ }^{2}$ The Rome Conference was held from May 7 to June 2, 1928. At the reviewing Conference from Rome attended 34 delegates from the 37 member states of the Union, including Romania, and delegates from 21 countries that were not members of the Berne Union. The Rome Act of 1928 was signed by a total of 28 countries including Romania, and by the deadline set by the conference (August 1, 1931) was ratified by 13 states.
} 
Thus, by the introduction of Article 6 bis it was recognised, for the author, the existence of a right that will permit it to claim the authorship of the work and to object to any distortion, mutilation or modification of the work which would be prejudicial to author' honour or reputation ${ }^{3}$.

\section{The notion of moral rights}

The moral rights of the author are inalienable and imprescriptible rights arising from copyright laws recognized by the most states $^{4}$ and whose content is not expressed in a pecuniary form. The moral rights represent the legal expression of the relationship between the work and its creator; they precede, survive and exert a permanent influence on the economic rights. Moral rights are independent of economic rights, the author of a work preserving these rights even after the transfer of its property rights.

The moral rights of the author and their legal protection did not constitute the subject to legislative concerns only very late, the main cause of this was the lack of reproduction means of literary and artistic works. The lack of possibility of multiplying the intellectual creations manuscripts made this operation to be done manual through writing, so it was very heavy and at the same time expensive.

In the foreign doctrine, the moral right was the subject of arguing, some authors disagree on neither its notion nor its definition. Thus, since 1897, the French writer Jules Lermina show that "artist's moral right is the right to defend the integrity of the work by its matter and form ${ }^{\prime \prime}$ and the French deputy Marcel Plaisant defined the moral right as "high sovereignty" which the author carries on the product of his talent and enables it to intervene whenever it finds that the integrity of the work is jeopardized and his personal interests are staked. Nicolas Stolfi, an acclaimed jurist of the time, suggested the name of "personal right ${ }^{\prime \prime}$ and jurist Jules Destrée called it the "right to respect".

In Romania, having regard to the provisions of article 3 of the Law on Literary and Artistic Property no. 126/1923 ${ }^{7}$, Professor Florin C. Tărăbuţă defined the moral right "as the author's right to create and to control its work and to claim from any person the respect which is due to anyone's personality expressed through the work" ${ }^{\prime \prime}$ and M. Beiller (former Romanian expert at the conference in Rome in 1928) show that "moral rights include: the right to the recognition of intellectual authorship of the work; the right to decide whether or not to show the work and the right to claim full and faithful reproduction of the work"1". Based

\footnotetext{
${ }^{3}$ See for details Ciprian Raul Romițan, Authors moral rights, Universul Juridic Publishing House, Bucharest, 2007 , pp. 76-78.

${ }^{4}$ In the common law legislations, such UK and USA, the moral rights of the author are almost ignored, they are not separately protected. According to art. 4-142 of the Copyright Act USA, the author has exclusive rights that can exercise in contractual terms in order to ensure the integrity of the work, but in the case in which an author transfer its right without enforcing such clauses, it loses the rights. In the view of this law, the moral rights of the author are a form of a property right called the right of publicity (eg, the California Civil Code, section 3344 is governed the right of publicity).

5 Jules Lermina, Report submitted to the International Literary and Artistic Association, Congress in Monaco 1897, cited Scondăcescu Barbu I., Dumitru I. Devesel, Constantin N. Duma, Law on literary and artistic property - commented and annotated, Romanian Book Publishing House, Bucharest, 1934, p. 60.

${ }^{6}$ Nicolas Stolfi, Traité théorique et pratique de la propriété littéraire et artistique, vol.1, Paris, 1916, p. 18, cited M. Beiller, Author's moral right, "Pandectele române", 4-th Part, 1929, p. 24.

7 According to Article 3 of the Law no. 126/1993, "author's right to control the published work, translations, reproductions or adaptations made from work, with the power to withdraw the assignment or authorization given through judicial summons, with the right of the author to seek justice if the publisher changes the work that was transferred, distort it, publish or reproduce it contrary to contractual conditions or in a manner injurious to author's reputation, subject to damages". The law was published in the Official Gazette No. 68 of 28 June 1923.

${ }^{8}$ Florin C.Tărăbuţă, The moral right of the author on his intellectual work, Printing and Bookbinding Prison "Văcăreşti", Bucharest, 1939, p. 45.

${ }^{9}$ M. Beiller, op. cit. p. 25.
} 
on Decree no. 321/1956 on copyright ${ }^{10}$, Professor Paul I. Demetrescu called the moral rights "personal rights of the author"11.

\section{Author's moral rights under the Law no. 8/1996}

From the analysis of art. 6 bis of the Berne Convention for the protection of literary and artistic works results that are recognized only two prerogatives of the moral right, namely: the right to paternity and the right to respect the integrity of the work. It also notes that under the provisions of par. 2), these prerogatives are limited in time.

Currently, as shown in doctrine ${ }^{12}$, although moral rights are recognized by the national laws of the European Union Member States, there is no regulation of these rights and some directives expressly state that their regulations do not apply to moral rights. In this sense, one can cite the following directives: Paragraph 28 of the preamble to Directive no. 93/83/EEC of 27 September 1993 on the coordination of certain rules concerning copyright and related rights applicable to satellite broadcasting and cable retransmission ${ }^{13}$; paragraph 21 of the Preamble and Art. 9 of the Directive no. 93/98/EEC of 29 October 1993 harmonizing the term of protection of copyright and certain related rights ${ }^{14}$; paragraph 28 of the preamble to Directive no. 96/9/EC of 11 March 1996 on the legal protection of databases ${ }^{15}$.

Although, over time, in Romania, the moral rights have been the subject of numerous scientific disputes ${ }^{16}$, since the adoption of Law no. 8/1996 on copyright and related rights ${ }^{17}$, any controversy ceased, because the Romanian legislator acknowledged the pre-eminence of moral rights, currently the legislation in force in our country being very generous and recognizing a wide range of specific moral rights (Article 10):

a) to decide whether, how and when the work will be disclosed to the public (the right to divulging the work);

b) to demand recognition of his authorship of the work;

c) to decide under what name the work will be disclosed to the public;

d) to demand respect for the integrity of the work and to oppose any modification or any distortion of the work if it is prejudicial to his honor or reputation (the right to respect the integrity of the work or the inviolability of the work);

e) to withdraw the work, subject to indemnification of any owners of exploitation rights who might be prejudiced by the exercise of the said withdrawal right (the right to withdraw).

The attribute of the author. The principle of the real author

According to article 4 alin. 1) of Law no. 8/1996, "unless proved otherwise, the person under whose name the work was first disclosed to the public shall be presumed to be the author thereof". Where "the work was disclosed to the public anonymously or under a

\footnotetext{
${ }^{10}$ Published in the Official Gazette no. 18 from 27 June 1956.

${ }^{11}$ Paul I. Demetrescu, The right of copyright, Scientific Annals of the University "Alexandru Ioan Cuza" Iaşi, (new series), Section III (Social Sciences), Tome II, Fasc. 1-2, 1956.

${ }^{12}$ Viorel Roş, Dragos Bogdan, Octavia Spineanu Matthew, Copyright and related rights, Treaty, All Beck Publishing House, Bucharest, 2005, pp. 197-198.

${ }^{13}$ Published in OJ no. L 248 of 6 October 1993.

${ }^{14}$ Published in OJ no. L 290/9 of 24 November 1993.

${ }^{15}$ Published in OJ no. L 77/20 of 27 March 1996.

${ }^{16}$ Constantin Stătescu, Civil Law. The contract of carriage. The rights of intellectual creation. Successions, Didactic and Pedagogic Publishing House, Bucharest, 1967, p 47; Aurelian Ionaşcu, Comşa Nicolae, Mircea Mureşan, Copyright in R.S.R., R.S.R. Academy Publishing House, Bucharest, 1969, pp. 85-99; Francis Deak, Stanciu D. Cărpenaru, Civil Law. Special contracts. Copyright. The right of inheritance, University of Bucharest, 1983, pp. 339-343; Yolanda Eminescu, Creative works and the law. A comparative look, R.S.R. Academy Publishing House, Bucharest, 1987, pp. 90-91.

${ }^{17}$ Published in the Official Gazette no. 60 of 26 March 1996, amended by Law no. 285/2004, published in Official Gazette no. 587 of 30 June 2004, as amended by Ordinance no. 123/2005, published in the Official Gazette no. 843 of 19 September 2005, amended by Law no. 329/2006 approving Government Emergency Ordinance no. 123/2005 amending and supplementing Law no. 8/1996 on copyright and related rights, published in the Official no. 657 of 31 July 2006.
} 
pseudonym that does not identify the author, the copyright shall be exercised by the person whether natural person or legal entity who discloses it to the public with the author's consent, as long as the latter does not disclose his identity" (art. 4 alin. 2).

Law no. 8/1996 on copyright and related rights enshrines the principle of the true author being the person protected by copyright. According to article 3 paragraphs 1) of the Law, "The natural person or persons who created the work shall be the author thereof". The authorship of a work belongs only to individuals, because only they have the specific qualities of the creator, namely: intelligence, personality, sensibility, faculty to create, to think, to formulate ideas and also to expose them in an original and personally form.

In order to recognise the authorship of a work, the law does not require any condition because it arises from the mere fact of creating the work, since the opera took a concrete form, even if is not completed. Following the creation of a work, the author acquires within the power of the law, also the status of copyright holder.

\section{The right to demand recognition of the authorship of the work}

The right to demand recognition of his authorship of the work called in the doctrine ${ }^{18}$ the "right of paternity of the work" is enshrined in art. 10 letters b) of the law and it is based on the need to respect the natural connection between the author and his work. The right to authorship is the most important prerogative that constitutes intellectual property rights in general and consists of recognizing the true author's right of a scientific, literary or artistic work.

As shown in the specialized literature ${ }^{19}$ entitled the right of has a positive aspect which consists in the right of the author to claim authorship no matter when, and a negative aspect including the right to oppose any act of usurpation, appealing this quality by third party. Recognition of the right of paternity imposed the obligation of all those who use short quotations, isolated articles or short excerpts from works without the author's consent, to indicate the source and author's name, unless this is impossible.

In a decision of 21 December 2004 the Court of Appeal noted that the right of authorship of the work is rooted in the law and the repeated failure to indicate the author's name on a movie promotional materials violate the dispositions of the law relating to the moral right of the author for the recognition of authorship ${ }^{20}$.

To the right to demand recognition of the authorship of the work, the author may not renounce or dispose of by acts inter vivos, but in the everyday life, the transmission of the right to third parties takes place, in this way. In this sense, it can be illustrated that in Romania, in almost all universities the transmission to third parties by developing, reproduction and sale of graduation paper or postgraduate and master. It seems that this situation is not new in our country. Thus, since 1887, in an article entitled "Pieces selected from Romanian plagiarisms" appeared in the "Constitutional" Newspaper of 10 May, stating that "often one and the same graduation paper served to many candidates" (...). The author of this article, who signed with the pseudonym "Lorellino" shows that it, is in the possession of more than 39 degree papers from the University of Bucharest, who actually are "textual translations, plagiarized more or less disguised after the French theses".

The French jurisprudence admits giving up to one of the prerogatives, but only as long as it is not final. In this respect, the French Court of Cassation agreed with a decision by a

\footnotetext{
${ }^{18}$ Ioan Macovei, Intellectual property law treaty, C.H. Beck Publishing House, Bucharest, 2010, p. 449.

${ }_{19}$ Yolanda Eminescu, Copyright. Law no. 8 of March 14, 1996, commented, Lumina Lex Publishing House, Bucharest, 1997, p 155; Ligia Dănilă, Copyright, All Beck Publishing House, Bucharest, 2005, p. 68; Bujorel Florea, Intellectual property law, Universul Juridic Publishing House, Bucharest, 2011, p. 67.

${ }^{20}$ Octavia Spineanu - Matei, Intellectual property. Jurisprudence, Hamangiu Publishing House, Bucharest, 2006, p. 229.
} 
court that, "declared valid an clause for anonymity, which provided by a person exercising its moral rights, could not constitute a final waiver on any of its powers"21.

As mentioned above, the right of authorship of the work belongs to only individuals and may also apply to derivative works, common or collective works, but only for the part created by the author ${ }^{22}$. An interesting case was the French Court of Cassation judgment regarding the intention of a co-author of a success movie to make a successful television series which was a sequel to the feature film. In order to make the TV series, the co-author held some talks with another company other than the one to which the producer transferred the property rights for the film and who was the film copyright holder. The Supreme Court agreed with the earlier decision of the Paris Court of Appeal of 13 July 1993 which established that on its features, a new work is not capable to create confusion with the previous film, and that the exclusive rights of the right holder are limited to the title ${ }^{23}$.

As previously stated, the right to authorship of the work involves the author's right to decide under under what name the work will be disclosed to the public. If the work is disclosed to the public without indicating the author's name, the author may ask the court to oblige the responsible person to perform any action it deems necessary to remedy the omission.

The author has the right to decide if the work will be disclosed to the public under his name, under a pseudonym or without indicating the names. If the work is published without the name or under pseudonym, the author can reveal its identity at any time ${ }^{24}$.

We have to mention that the will of an author on how to write its name (full name, initials, etc.) has to be respected exactly. Failing to respect author's will can constitute not only a violation of the right to the name, but also of the right of authorship ${ }^{25}$.

Once born, the right to authorship is inalienable. The right to authorship of the work is transmitted by inheritance indefinitely, according to civil law. If there are no heirs, the exercise of these rights rests to the collective management organisation mandated by the author during his lifetime or, failing a mandate, to the collective administration organization with the largest membership in the area of creation concerned.

The transmission of the right exercise means the possibility of the successors to claim other people to recognize that their predecessor is the author of the work. In other words, the copyright in a procedural meaning and not material is transmitted to the successors ${ }^{26}$.

\section{Bibliography}

Circa A., The protection of intellectual property rights. News and perspectives, Universul Juridic Publishing House, Bucharest, 2013;

Bucharest, 2011;

Bodoaşcă T., Intellectual Property Law, Universul Juridic Publishing House,

Florea B., Intellectual property law, Universul Juridic Publishing House, Bucharest, 2011; 2010

Macovei I., Intellectual property law treaty, C.H. Beck Publishing House, Bucharest,

\footnotetext{
${ }^{21}$ French Court of Cassation, decision of 5 May 199, in Andre Bertrand, Le droit d'auteur et les droits voisins, Dalloz, Paris, 1999, p. 272.

${ }^{22}$ Andre Bertrand, op. cit., p. 270.

${ }^{23}$ French Court of Cassation, Civil Division, judgment of 19 February 2002. For details see Gheorghe Gheorghiu, Audiovisual works, Lumina Lex Publishing House, Bucharest, 2004, pp. 362-366.

${ }^{24}$ Viorel Roş, Intellectual Property Law, Global Lex Publishing House, Bucharest, 2001, pp. 113-114.

25 Adrian Circa, The protection of intellectual property rights. News and perspectives, Universul Juridic Publishing House, Bucharest, 2013, p. 191.

${ }^{26}$ Teodor Bodoaşcă, Intellectual Property Law, Universul Juridic Publishing House, Bucharest, 2011, p. 67.
} 

2007;

Romiţan C. R., Authors moral rights, Universul Juridic Publishing House, Bucharest,

Spineanu Matei O., Intellectual property. Jurisprudence, Hamangiu Publishing House, Bucharest, 2006;

Roş V., Bogdan D., Spineanu Matei O., Copyright and related rights, Treaty, All Beck Publishing House, Bucharest, 2005;

Dănilă L., Copyright, All Beck Publishing House, Bucharest, 2005;

Gheorghiu G., Audiovisual works, Lumina Lex Publishing House, Bucharest, 2004;

Roş V., Intellectual Property Law, Global Lex Publishing House, Bucharest, 2001;

Bertrand A., Le droit d'auteur et les droits voisins, Dalloz, Paris, 1999;

Eminescu Y., Copyright. Law no. 8 of March 14, 1996, commented, Lumina Lex Publishing House, Bucharest, 1997;

Eminescu Y., Creative works and the law. A comparative look, R.S.R. Academy Publishing House, Bucharest, 1987;

Deak F., Cărpenaru S., Civil Law. Special contracts. Copyright. The right of inheritance, University of Bucharest, 1983;

Ionaşcu A., Comşa N., Mureşan M., Copyright in R.S.R., R.S.R. Academy Publishing House, Bucharest, 1969;

Stătescu C., Civil Law. The contract of carriage. The rights of intellectual creation. Successions, Didactic and Pedagogic Publishing House, Bucharest, 1967;

Demetrescu P., The right of copyright, Scientific Annals of the University "Alexandru Ioan Cuza" Iaşi, (new series), Section III (Social Sciences), Tome II, Fasc. 1-2, 1956;

Tărăbuţă F., The moral right of the author on his intellectual work, Printing and Bookbinding Prison "Văcăreşti", Bucharest, 1939;

Lermina J., Report submitted to the International Literary and Artistic Association, Congress in Monaco 1897, cited Scondăcescu Barbu I., Dumitru I. Devesel, Constantin N. Duma, Law on literary and artistic property - commented and annotated, Romanian Book Publishing House, Bucharest, 1934;

Stolfi N., Traité théorique et pratique de la propriété littéraire et artistique, vol.1, Paris, 1916, p.18, cited M. Beiller, Author's moral right, "Pandectele române", 4-th Part, 1929. 